rev. hist. (São Paulo), n. 171, p. 49-82, jul.-dez., 2014 http://dx.doi.org/10.11606/issn.2316-9141.rh.2014.89007

$$
\begin{array}{r}
\text { Contato } \\
\text { Márcio Couto Henrique } \\
\text { Trav. Dr. Moraes, n 780, apto. 205 } \\
66045-590 \text { - Belém - Pará } \\
\text { E-mail: mchenrique@hotmail.com } \\
\text { Laura Trindade de Morais } \\
\text { Rodovia Augusto Montenegro, alameda Santa } \\
\text { Maria n 400d } \\
66820-050 \text { - Belém - Pará } \\
\text { E-mail: laurashj@hotmail.com }
\end{array}
$$

\title{
ESTRADAS LÍQUIDAS, COMÉRCIO SÓLIDO: ÍNDIOS E REGATÕES NA
}

AMAZÔNIA (SÉCULO XIX)

\section{Márcio Couto Henrique}

Universidade Federal do Pará Laura Trindade de Morais ${ }^{* *}$

Universidade Federal do Pará

\section{Resumo}

O artigo analisa as relações entre os índios e os comerciantes ambulantes que, na Amazônia do século XIX, eram conhecidos como regatões. Com base em documentos da época, constata-se que nem sempre os índios foram vítimas ingênuas e passivas diante dos regatões e que é necessário enfatizar a dimensão simbólica das trocas, a fim de recuperar o protagonismo indígena nas relações estabelecidas com os comerciantes e com as mercadorias que eles vendiam.

\section{Palavras-chave}

Índios - regatões - Amazônia.

* Artigo resultante do projeto de pesquisa intitulado "O soldado da fé: frei Pelino e a catequese dos Munduruku (1871-1881)", atualmente desenvolvido junto à Pró-Reitoria de Pesquisa da Universidade Federal do Pará (Propesp/UFPA).

${ }^{* *}$ Doutor em Ciências Sociais. Sócio efetivo do Instituto Histórico e Geográfico do Pará. Professor da Faculdade de História e do Programa de Pós-Graduação em História.

${ }^{* * *}$ Mestranda em História no Programa de Pós-Graduação em História e bolsista do Conselho Nacional de Desenvolvimento Científico e Tecnológico (CNPq). 
rev. hist. (São Paulo), n. 171, p. 49-82, jul.-dez., 2014 http://dx.doi.org/10.11606/issn.2316-9141.rh.2014.89007
Márcio Couto Henrique \& Laura Trindade de Morais Estradas líquidas, comércio sólido: índios e regatões na Amazônia (século XIX)

\title{
LIQUID ROADS, SOLID
}

TRADE:

INDIANS AND

REGATÕES IN THE

AMAZON

(XIX CENTURY)

Contato Márcio Couto Henrique

Trav. Dr. Moraes, $n^{\circ} 780$, apto. 205 66045-590 - Belém - Pará

E-mail: mchenrique@hotmail.com

Laura Trindade de Morais Rodovia Augusto Montenegro, alameda Santa

Maria $\mathrm{n}^{\circ} 400 \mathrm{~d}$

66820-050 - Belém - Pará

E-mail: laurashj@hotmail.com

\section{Márcio Couto Henrique}

Universidade Federal do Pará Laura Trindade de Morais

Universidade Federal do Pará

\begin{abstract}
The paper analyzes the relationship between Indians and itinerant traders that in Amazon nineteenth century were known as regatões. Based on contemporary documents, it appears that the Indians were not always naive and passive victims in front of regatões and what is required to emphasize the symbolic dimension of trade in order to recover the indigenous leadership in the relationships established with traders and the goods they sold.
\end{abstract}

\section{Keywords}

Indians - regatões - Amazon. 


\section{Os filhos da ventura}

Com o decreto $\mathrm{n}^{\circ} 426$, de 24 de julho de 1845, a catequese dos índios do Brasil foi entregue aos missionários capuchinhos que, a partir de então, passaram a atuar como missão oficial do Império. Conforme observou Manuela Carneiro da Cunha, "desde Pombal, uma retórica mais secular de 'civilização' vinha se agregando à da catequização. E 'civilizar' era submeter às leis e obrigar ao trabalho". ${ }^{1}$ Nesse sentido, o decreto de 1845 recuperou experiências de outras propostas de civilização dos índios, o que incluía, além da catequese, a criação de escolas para crianças nas aldeias, o desenvolvimento dos ofícios e "artes mecânicas", o estímulo à produção de alimentos para autossustentação e comercialização do excedente, a atração dos índios considerados "errantes" e a prática da propriedade coletiva. ${ }^{2}$ Havia, também, a preocupação com as fronteiras nacionais, ameaçadas pelos países vizinhos. ${ }^{3}$

Com o passar dos anos, foi-se percebendo que, apesar dos gastos e esforços do trabalho dos missionários, os índios continuavam presos às suas antigas tradições, recusando-se a trabalhar além de suas próprias necessidades. Diante da ineficácia do projeto de catequese e civilização dos índios, as autoridades começaram a refletir sobre suas possíveis causas. Nas províncias do Pará e Amazonas, em grande medida, as razões do fracasso

1 CUNHA, Manuela Carneiro da. Política indigenista nos século XIX. In: História dos índios no Brasil. São Paulo: Companhia das Letras, 1998 [1992], p. 142. Sobre "a ideia iluminista da catequese como instrumento de civilização", conferir também, POMPA, Cristina. Para uma antropologia histórica das missões. In: MONTERO, Paula (org.). Deus na aldeia: missionários, índios e mediação cultural. São Paulo: Globo, 2006, p. 111-142.

2 Para uma discussão sobre a retomada da atividade missionária no Brasil do século XIX, conferir SAMPAIO, Patrícia Melo. Política indigenista no Brasil imperial. In: GRINBERG, Keila $\mathscr{E}$ SALLES, Ricardo. O Brasil imperial, vol. I: 1808-1831. Rio de Janeiro: Civilização Brasileira, 2009, p. 175-206 e SPOSITO, Fernanda. Nem cidadãos, nem brasileiros: indígenas na formação do Estado nacional brasileiro e conflitos na província de São Paulo (1822-1845). Tese de doutorado, FFLCH-USP. São Paulo, 2006; Com relação à agricultura na Amazônia oitocentista, conferir NUNES, Francivaldo Alves. Sob o signo do moderno cultivo: Estado imperial e agricultura na Amazônia. Tese de doutorado, Programa de Pós-Graduação em História da Universidade Federal Fluminense. Rio de Janeiro, 2011. Com relação às escolas para índios, conferir HENRIQUE, Márcio Couto. O soldado-civilizador: Couto de Magalhães e os índios no Brasil do século XIX. In: ALVES, Claudia \& NEPOMUCENO, Maria de Araújo (orgs.). Militares e educação em Portugal e no Brasil, v. 1.1 ed. Rio de Janeiro: Faperj; Quartet, 2010, p. 45-83.

3 Para a relação entre as missões e as fronteiras nacionais, conferir MEDEIROS, Vera B. Alarcón. Incompreensível colosso: a Amazônia no início do Segundo Reinado (1840-1850). Tese de doutorado, Universidade de Barcelona, Programa de Doutorado Estado e Sociedade na América e África, 2006. 
da atividade missionária foram atribuídas aos regatões. Assim, por exemplo, Jerônimo Francisco Coelho, presidente da província do Pará, dizia que

os principais corruptores dos indígenas são essas quadrilhas de canoas de regatões, mascates ou quitandeiros dos rios, que os cruzam e penetram por todas as partes, incutindo falsas ideias nos ânimos dos índios, iludindo-os com embustes, suscitando-lhes terrores infundados e dando-lhes maus conselhos para os afastar da obediência e aldeamento regular, apresentando-se como seus amigos, porém com ardiloso e perverso desígnio de conservarem o exclusivo monopólio de suas relações comerciais, a fim de os poderem lesar à vontade e impunemente, visto que os índios não têm claro conhecimento dos valores dos gêneros que permutam. ${ }^{4}$

Ao se referir à proibição do comércio dos regatões na província do Pará, o vice-presidente da província do Amazonas dizia, em 1852, que "esta maneira de comerciar é não só imoral, como muito contrária à civilização dos povos e ainda também por ser uma das causas principais porque muitas povoações têm desaparecido e algumas vilas se encontram quase abandonadas". ${ }^{5}$

Conforme demonstrou Simeia Lopes, a partir da década de 1840, os presidentes da província do Pará tinham como preocupação central a reestruturação do comércio interno e de toda a vida social da região, abalados pelas lutas de independência (1823) e pela Cabanagem (1835-1840), movimento social que provocou profundo abalo na economia da região. ${ }^{6}$ Nesse contex-

\footnotetext{
4 Governo do Pará. Falla dirigida pelo Exm. Sr. conselheiro Jeronimo Francisco Coelho, prezidente da provincia do Gram Pará á Assembléa Legislativa Provincial na abertura da $2^{\mathrm{a}}$ sessão ordinaria da $6^{\text {a }}$ legislatura no dia $1^{\circ}$ de outubro de 1849. Pará: Typ. de Santos \& filhos, 1849, p. 82-83.

5 Governo do Amazonas. Falla dirigida á Assemblea Legislativa da provincia do Amazonas, na abertura da $1^{\mathrm{a}}$ sessão ordinaria da $1^{\mathrm{a}}$ legislatura, pelo Exm. vice-prezidente da mesma provincia, o dr. Manoel Gomes Correa de Miranda, em 5 de setembro de 1852. Capital do Amazonas: Typ. de M. da S. Ramos, 1852, p. 20. O comércio de regatões foi proibido na província do Pará pela resolução $\mathrm{n}^{\circ}$ 182, de 9 de dezembro de 1850. A legislação acompanha os embates entre os grupos que defendiam e os que condenavam este tipo de comércio. Apesar da proibição em 1850, encontra-se entre as leis do Pará o "Ofício de 3 de dezembro de 1850, declarando que com um só alvará de licença pode uma canoa de regatão percorrer diferentes Municípios, dentro de um ano". Conferir Governo do Pará. Colecção das leis da provincia do Gram-Pará, tomo XII, parte II, 1850. Pará: Typ. de Santos $\mathcal{E}$ Filhos, 1851. Com a lei n 246 , de 6 de setembro de 1854, o governo do Pará derrogou a resolução nº 182, que proibiu o comércio de regatão. Conferir: Governo do Pará. Colecção das leis da provincia do Gram-Pará, tomo XVI, 1854. Pará: Typ. de Santos $\mathcal{E}$ Filhos, 1854, Lei no 246, de 6 de setembro de 1854.

6 LOPES, Simeia de Nazaré. O comércio interno no Pará oitocentista: atos, sujeitos sociais e controle entre 1840-1855. Dissertação de mestrado, NAEA. Belém, 2002, p. 14. Sobre os efeitos da Cabanagem na região amazônica, conferir RICCI, Magda. Cabanagem, cidadania e identidade revolucionária: o problema do patriotismo na Amazônia entre 1835 e 1840. Tempo, v. 11. Revista do
} 
to, os regatões apareciam, ao mesmo tempo, como inimigos da catequese e obstáculos ao desenvolvimento do comércio regional. Mas quem seriam esses tão temidos regatões? Uma definição desse personagem está presente na resolução $n^{\circ}$ 182, que proibiu a atividade na província do Pará:

São canoas de regatão as que navegam fora dos portos das cidades, vilas, freguesias e povoados da província, contendo secos e molhados, como verdadeiras lojas ou tabernas flutuantes, vendendo e comprando ou permutando gêneros e objetos de comércio pelos sítios, fazendas, fábricas, engenhos e feitorias. ${ }^{7}$

A definição chama a atenção para aspecto fundamental dessa atividade: a mobilidade. Do ponto de vista das autoridades das províncias, navegar "fora dos portos" implicava não ser alcançado pelos mecanismos de arrecadação de impostos, nem por outras instâncias governamentais que poderiam fiscalizar as relações de troca entre regatões e índios, por exemplo. Na prática, porém, recaíam sobre a prática dos regatões pesados impostos, o que era alvo de críticas de políticos como Tavares Bastos. Em obra publicada em 1866, dizia ele que

Cada canoa empregada no comércio de regatão sofre as seguintes taxas: no Pará, 175\$000 de imposto provincial e $253 \$ 000$ do municipal; ao todo 200\$000. No Alto-Amazonas, sendo o imposto provincial $100 \$ 000$ e o municipal $8 \$ 000$, o total das taxas é $108 \$ 000$. Tais impostos são evidentemente excessivos. Só os 8\% no desembarque da borracha produzem 200:000\$000 no Pará, um quarto da receita desta província, segundo o orçamento de 1864.

A taxa sobre canoas de regatão e lojas fora dos povoados merece maior reparo. ${ }^{8}$

Tavares Bastos fazia eco às ideias de José Vieira Couto de Magalhães, ex-presidente da província do Pará, que defendia o fim dos altos impostos cobrados aos regatões, o que, segundo ele, tornaria esse tipo de atividade mais vantajosa e atrairia pessoas mais honestas no trato com os índios. De acordo

Departamento de História da UFF, Rio de Janeiro, 2006, p. 15-40; HARRIS, Mark. Rebellion on the Amazon: The Cabanagem, race, and popular culture in the North of Brazil, 1798-1840. Cambridge: Cambridge University Press, 2010; BARRIGA, Letícia Pereira. Entre leis e baionetas: Independência e Cabanagem no médio Amazonas (1808-1840). Dissertação de mestrado, Programa de Pós-Graduação em História da Universidade Federal do Pará. Belém, 2014.

7 [Nota avulsa]. Treze de Maio, Belém, 4 jan. 1851, p. 1. Simeia Lopes chamou a atenção para a ambiguidade dessa definição legal e as consequentes dificuldades na aplicação da lei. LOPES, Simeia de Nazaré. O comércio interno..., op. cit., 2002.

8 TAVARES BASTOS, Aureliano Cândido. O valle do Amazonas. Rio de Janeiro: B. L. Garnier, 1866, p. 283. 
com Couto de Magalhães, os regatões enganavam os índios para compensar com lucros ilícitos as altas taxas que eram obrigados a pagar para trabalhar legalmente. Dizia ele: "entendo que o melhor meio de diminuir os males produzidos pelo comércio de regatão será o de facilitá-lo completamente, permitindo a entrada pelos rios e fazendo cessar o imposto quase proibitivo e pesado que eles pagam". 9 Outros defendiam a maior taxação dos regatões, como o fez Francisco Maria Corrêa de Sá e Benevides, presidente da província do Pará, em 1876:

mais uma vez vos será dito que é o maior inimigo da catequese o negociante regatão. (...) Tendes providenciado substituindo o imposto fixo que pagavam os regatões pelo de 25\$000 reis, de município em município. Parece que dos impostos poderia este ser aumentado sem prejuízo público. ${ }^{10}$

Para escapar às altas taxas que lhes eram cobradas, os regatões se empenhavam em atuar na clandestinidade, no que eram beneficiados pelo emaranhado de rios, furos e igarapés da região amazônica, que facilitavam a eles escapar dos postos de vigilância e arrecadação de impostos. O comércio era feito, então, com base em redes de relações sociais tecidas com quilombolas, pequenos produtores, comerciantes locais e indígenas, constituindo relação comercial alternativa ao abastecimento da população. Por sua vez, os presidentes de província se preocupavam com a construção de mecanismos de controle do comércio de regatão, tais como portos de fiscalização nos diferentes rios, fixação de coletorias, alfândegas e mesas de rendas situadas em pontos estratégicos. ${ }^{11}$

Era pelos rios que se transportavam as produções do interior em direção ao circuito mercantil realizado nos portos e armazéns da cidade. A canoa era o principal veículo utilizado para transportar e negociar com os regatões os produtos cultivados em pequenas roças e extraídos na floresta ou para o contrabando de gêneros alimentícios, tais como carne verde, farinha, arroz, feijão, milho e mandioca. No relatório da presidência da província do

\footnotetext{
9 Governo do Pará. Relatorio dos negocios da provincia do Pará. At head of title: Dr. Couto de Magalhães, presidente do Pará, 1864. Pará: Typ. de Frederico Rhossard, 1864, p. 10-11. Para uma análise do projeto de Couto de Magalhães para a civilização dos índios, conferir HENRIQUE, Márcio Couto. O general e os tapuios: linguagem, raça e mestiçagem em Couto de Magalhães (1864-1876). Dissertação de mestrado, Programa de Pós-Graduação em Ciências Sociais da UFPA. Belém, 2003.

${ }^{10}$ Governo do Pará. Relatorio apresentado pelo Exm. Sr. dr. Francisco Maria Corrêa de Sá e Benevides, presidente da provincia do Pará, á Assembléa Legislativa Provincial na sua sessão solemne de installação da $20^{\mathrm{a}}$ legislatura, no dia 15 de fevereiro de 1876. Pará: Travessa de São Matheus, 1876, p. 42.

${ }^{11}$ LOPES, Simeia de Nazaré. 0 comércio interno..., op. cit., 2002, p. 14.
} 
Amazonas, de 1856, consta um quadro com informações sobre as canoas que se empregaram no comércio de regatão naquela província, no ano anterior.

Tabela 1:

Canoas empregadas no comércio de regatão na província do Amazonas (1855) ${ }^{12}$

\begin{tabular}{|c|c|c|c|}
\hline Estações onde despacharam & $\mathbf{N}^{\mathbf{o}}$ de canoas & Toneladas & Equipagem \\
\hline Repartição central na capital & 15 & 120 & 58 \\
\hline Coletoria da Vila Bela de Imperatriz & 8 & 39 & 22 \\
\hline Coletoria da Vila de Maués & 26 & 52 & 67 \\
\hline Coletoria da Vila de Silves & 14 & 63 & 33 \\
\hline Coletoria da freguesia de Serpa & 11 & 68,5 & 34 \\
\hline Coletoria da freguesia de Canumá & 7 & 49 & 16 \\
\hline Coletoria da freguesia de Borba & & & \\
\hline Coletoria da Vila de Barcelos & 13 & & \\
\hline Coletoria da freguesia de Coary & & 14 & 28 \\
\hline Coletoria da cidade de Tefé & 6 & $\mathbf{4 0 5 , 5}$ & $\mathbf{2 5 8}$ \\
\hline Total & $\mathbf{1 0 0}$ & & \\
\hline
\end{tabular}

Note-se que havia, então, um total de 100 canoas de regatões apenas na província do Amazonas. Estes dados referem-se às canoas registradas pelas autoridades, sendo que o número efetivo delas poderia ser bem maior, em função das estratégias utilizadas pelos comerciantes para enganar a fiscalização como, por exemplo, obter autorização para uma canoa e usá-la para várias utilizadas no mesmo serviço.

A partir de informações da coletoria de Óbidos, no oeste do Pará, Tavares Bastos constatou 23 canoas empregadas no comércio de regatão. ${ }^{13}$ Percorrendo a mesma região poucos anos depois, Ferreira Pena registrava que

\footnotetext{
${ }^{12}$ Governo do Amazonas. Relatorio apresentado á Assembléa Legislativa Provincial, pelo Exc. Sr. doutor João Pedro Dias Vieira, dignissimo presidente desta provincia, no dia 8 de julho de 1856 por occasião da $1^{\text {a }}$ sessão ordinaria da $3^{\text {a }}$ legislatura da mesma Assembléa. Barra do Rio Negro: Typ. de F. J. S. Ramos, 1856, anexo 14.

13 TAVARES BASTOS, Aureliano Cândido. O valle do Amazonas..., op. cit., 1866, p. 283.
} 
"30 canoas, chamadas de regatões, além de outras menores, estão em giro contínuo pelos rios e lagos, empregando-se no tráfico dos gêneros do município e dos de alguns distritos vizinhos, ou navegando entre o seu porto e o de Belém". ${ }^{14}$ Número parecido Barbosa Rodrigues registrou em Santarém, onde ele identificou "26 regatões ou comércio ambulante para o interior". ${ }^{15}$ Em Itaituba, também no oeste do Pará, Barbosa Rodrigues observou que, além das casas comerciais, havia "o comércio ambulante, formado por 12 canoas de regatões" ${ }^{16}$ Conforme demonstram estes autores, era dessa região que saía grande parte dos produtos silvestres que alimentavam o comércio da Amazônia, muitos dos quais obtidos a partir da utilização da mão-de-obra indígena, como os Munduruku e Maué.

A grande questão para as autoridades diante do comércio dos regatões era "como reter essa prática ilícita se cada quintal das casas à margem do rio servia como um porto?"17 De certo modo, a mobilidade dos regatões acompanhava a mobilidade de grande parte da população amazônica, que se movimentava sazonalmente entre suas habitações a beira dos rios e suas roças ou pontos de extração dos produtos silvestres espalhados pela floresta. Mário Ypiranga Monteiro, em estudo pioneiro sobre o tema, fez referência à "mobilidade assustadora" desses comerciantes. ${ }^{18}$ Tratava-se, de fato, de atividade "flutuante", que o aparelho do Estado não conseguia acompanhar plenamente.

Em ofício enviado ao Ministério da Agricultura, em 1864, o presidente da província do Pará explicava que os regatões "formam o comércio ambulante e representam nesta província o papel dos que no sul do Império chamamos mascates. São de ordinários portugueses, verdadeiros filhos da ventura, que não há imoralidade que não cometam para aumentar seus lucros". ${ }^{19}$ Novamente, faz-se referência à mobilidade dos regatões, comparados

\footnotetext{
${ }^{14}$ FERREIRA PENA, Domingos Soares. A região occidental da província do Pará. Pará: Typ. do Diário de Belém, 1869, p. 18.

${ }^{15}$ RODRIGUES, Joaquim Barbosa. Exploração e estudo do vale do Amazonas. Rio Tapajós. Rio de Janeiro: Typ. Nacional, 1875, p. 7.

${ }^{16}$ Idem, p. 60

17 LOPES, Simeia de Nazaré. O comércio interno..., op. cit., p. 68.

${ }^{18}$ Monteiro procurou justificar o trabalho dos regatões, demonstrando como "apesar da manifesta ojeriza de muitos, o regatão foi um agente socializador". Conferir MONTEIRO, Mário Ypiranga. O regatão (notícia histórica). Manaus: Edições Planície, 1958, p. 86. Visão semelhante pode ser encontrada em GOULART, José Alípio. O regatão: mascate fluvial da Amazônia. Rio de Janeiro: Editora Conquista, 1968.

${ }^{19}$ Brasil. Ministério da Agricultura. Relatório apresentado à Assembléa Geral Legislativa na $3^{\text {a }}$ sessão da $12^{\mathrm{a}}$ legislatura pelo Ministro e Secretário de Estado dos Negócios d'Agricultura, Com-
} 
ao mascate das regiões sul e sudeste do Brasil a fim de facilitar a compreensão deste elemento típico das paisagens amazônicas. ${ }^{20}$ Por outro lado, a definição dos portugueses como "verdadeiros filhos da ventura" reforça a noção de mobilidade. ${ }^{21}$

Mário Ypiranga Monteiro remete a Portugal a origem dos regatões, o que ele denomina como "um fenômeno socioeconômico aculturado". ${ }^{22}$ Em Portugal, eles eram vendedores ambulantes a varejo de gêneros alimentícios, que percorriam as ruas oferecendo de porta em porta suas mercadorias. Mas, "regatão em canoa, só no Brasil". ${ }^{23}$ O surgimento do mascate fluvial na Amazônia estaria, portanto, ligado às características ambientais da região, em função da existência de grande número de "estradas líquidas" (rios, lagos, furos e igarapés) que marcam sua geografia e que não eram atendidas pelos navios de maior porte.

Exatamente por causa das características ambientais da região, os regatões precisavam da contribuição dos índios, fundamental para diminuir os riscos das viagens. Afinal, os comerciantes estavam sujeitos aos caprichos das intempéries, às chuvas torrenciais, à força das correntezas, aos trechos encachoeirados, aos troncos de árvores que deslizavam pelos rios, aos repentinos bancos de areia ou às flechas envenenadas de muitos índios ao longo do percurso. Cite-se, ainda, o emaranhado de caminhos possíveis nas confluências dos rios.

mercio e Obras Públicas, Jesuíno Marcondes de Oliveira e Sá. Rio de Janeiro: Typ. Universal de Laemmert, 1865, anexo D, p. 2-3.

${ }^{20} \mathrm{O}$ mascate era um mercador ambulante que percorria as ruas dos arraiais e vilas vendendo objetos manufaturados. No século XVIII, esta alcunha foi dada aos portugueses do Recife pelos brasileiros de Olinda, o que originou o nome da Guerra dos Mascates, iniciada em 1710, entre estes dois grupos. Conferir VENÂNCIO, Renato Pinto \& FURTADO, Júnia Ferreira. Comerciantes, tratantes e mascates. In: PRIORE, Mary Del (org.). Revisão do paraíso: os brasileiros e o Estado em 500 anos de história. Rio de Janeiro: Campus, 2000, p. 95-113; BOTELHO, Ângela Vianna E REIS, Liana Maria. Dicionário histórico do Brasil Colônia e Império. Belo Horizonte: Autêntica, 2002.

${ }^{21}$ Cabe lembrar, aqui, a discussão de Sérgio Buarque de Holanda sobre o "espírito aventureiro" dos portugueses. Segundo o autor, "o que o português vinha buscar era, sem dúvida, a riqueza, mas riqueza que custa ousadia, não riqueza que custa trabalho". HOLANDA, Sérgio Buarque. Raízes do Brasil. 26 edição. São Paulo: Companhia das Letras, 1995, p. 49. No século XIX, era recorrente essa associação entre o ofício de regatão e a obtenção de altos lucros com pouco trabalho. Referindo-se aos regatões que atuavam no rio Gurupi, Gustavo Dodt lamentava "a afluência de um número mais crescido de pessoas ignorantes e viciosas, que se dedicam a este tráfego só por causa da sua antipatia a um trabalho regular". DODT, Gustavo. Descrição dos rios Parnaíba e Gurupi. Belo Horizonte: Ed. Itatiaia, 1981, p. 95.

${ }^{22}$ MONTEIRO, Mário Ypiranga. O regatão..., op. cit., 1958, p. 17.

${ }^{23}$ GOULART, José Alípio. O regatão..., op. cit., 1968, p. 21. 
José Veríssimo definiu o regatão como "um produto original da Amazônia". ${ }^{24}$ No período imperial, os portugueses dominaram este ofício, que também era exercido por espanhóis, bolivianos, peruanos, franceses, ingleses, além de negros e mestiços das mais variadas matizes. Convém salientar que a presença de estrangeiros nessa atividade se dava à revelia das leis, que proibiam o ofício a não brasileiros. A partir da República, destacaram-se entre os regatões os sírios, armênios, marroquinos e turcos. ${ }^{25}$

O aspecto "flutuante" da atividade do regatão tornava sua definição bastante imprecisa para muitos homens daquela época. José Veríssimo, por exemplo, dizia:

eis aí uma coisa, ou antes uma pessoa, difícil de definir. É negociante e não é, tem alguma coisa de pirata. Anda embarcado. Às vezes tem a voz meiga, então o coração é mau. Outras vezes, sob o exterior de pomba, oculta as garras do gavião. É nômade. Sem ter a coragem do beduíno, parece-se com ele. ${ }^{26}$

Dessa forma, o regatão era visto como a personificação da ambiguidade. Necessário, mas temido. Negociante, mas pirata em potencial, saqueador das coisas alheias. A voz meiga, o coração mau. Civilizado, mas nômade, o que o aproximava dos "selvagens" que deveria civilizar.

Na verdade, o regatão fazia parte de uma rede maior, que tinha início bem distante dos rios e igarapés onde ele atuava. Numa das pontas desse comércio estava o comerciante do interior, que "se submete de corpo e alma a pagar tudo quanto pede ou lhe enviam de Belém, que se sujeita a todos os riscos de embarque e desembarque dos gêneros. Finalmente, que aceita submisso quantas imposições forem lembradas por seus credores". ${ }^{27}$ Eis, então, dois personagens dessa rede, o comerciante residente no interior e o credor residente na capital do Estado, Belém e, a partir da criação da província do Amazonas, Manaus. Conforme demonstrou Simeia Lopes, "algumas canoas pertenciam a grandes firmas aviadoras de Belém, que se valiam de

\footnotetext{
${ }^{24}$ VERÍSSIMO, José. Estudos amazônicos. Belém: UFPA, 1970, p. 23. Conferir, ainda, VERÍSSIMO, José. A pesca na Amazônia. Rio de Janeiro: Livraria Clássica de Alves \& C., 1895.

${ }^{25}$ Para uma interpretação da ação dos regatões hebraicos e turcos na Amazônia, conferir MORAIS, Raimundo. Na planície amazônica. Brasília: Senado Federal, Conselho Editorial, 2000 [1926], p. 37-42. Ver, ainda, PEREIRA, José Veríssimo da Costa. Regatões. In: IBGE. Tipos e aspectos do Brasil. Rio de Janeiro: IBGE, 1956, p. 34-38.

${ }^{26}$ VERÍSSIMO, José. Primeiras páginas (Viagem no sertão - quadros paraenses - estudos). Belém: Typographia Guttemberg, 1878, p. 105-106.

${ }^{27}$ O rio Tapajós. Diário de Belém, Belém, 22 de março de 1876, p. 1.
} 
sua influência política para proteger a atuação de intermediários no lucrativo comércio". ${ }^{28} \mathrm{O}$ interesse desses proprietários dificultava, inclusive, a ação reguladora e fiscalizadora das autoridades da província.

Ocorre que, para pôr em circulação imediata as mercadorias que comprava, o comerciante do interior precisava "constituir um preposto, um alter-ego que o representa em todos os pontos do distrito mais ou menos habitados, e que procure tirar da boa fé do infeliz índio a compensação das imposições que lhe são feitas pelo credor". Para isso, ele "contrata um caixeiro, mete-o em uma canoa com mercadorias e aí temos em cena o regatão", 29 o terceiro elemento da rede de comércio. De todo modo, este não era o único meio de abastecimento dos comerciantes, pois, segundo José Alípio Goulart, "o sistema de abastecimento dos regatões não obedecia a nenhuma fórmula estratificada", podendo ser feito através das "casas aviadoras" ${ }^{\prime 30}$ localizadas em Belém ou Manaus, de comerciantes menores instalados nas sedes dos municípios do interior, de outros regatões ou de barracões nos seringais.

Atolado em dívidas, o comerciante do interior depositava todas as suas esperanças - e ameaças - no regatão. Aos olhos das autoridades da época, uma única motivação guiava esses dois personagens, a cobiça, e o lugar do índio nessa relação era sempre o de vítima. Na cobiça de ambos, comerciante do interior e regatão, estaria a origem dos meios utilizados por este último para enganar os índios.

Assim como as autoridades, os regatões eram conhecedores dos objetos que mais atraíam os índios e dos quais suas canoas estavam sempre abarrotadas: tecidos, bebidas espirituosas (cachaça), farinha e outros gêneros alimentícios e "bugigangas" (pentes, espelhos, anzóis, agulhas, linha de coser), sal, fósforos, munição eram trocados por borracha, castanhas, cacau, salsa, óleo de copaíba, guaraná, canela, cravo, salsaparrilha, piaçava, entre outros produtos extraídos pelos índios na floresta.

Em relatório de 1862, o presidente da província do Pará, Francisco Carlos de Araújo Brusque, apresentou alguns exemplos de trocas feitas entre índios e regatões no alto Gurupi e no rio Capim, a partir de relatos que teria ouvi-

${ }^{28}$ LOPES, Simeia de Nazaré. 0 comércio interno..., op. cit., p. 77.

${ }^{29}$ Idem.

${ }^{30}$ GOULART, José Alípio. Regatão..., op. cit., 1968, p. 46. "Aviar" significava fornecer mercadoria a prazo, sendo que o pagamento seria feito com produtos extraídos da floresta. A pessoa que fornecia as mercadorias era chamada de "aviador", dono das chamadas "casas aviadoras". Conferir McGRATH, David. Parceiros no crime: o regatão e a resistência cabocla na Amazônia tradicional. Novos Cadernos NAEA, vol. 2, nº 2, dez. 1999, p. 57-72. 
do dos próprios índios, possivelmente Tembé, que estiveram na capital do Pará. No rio Gurupi, em troca de um corte de calças de algodão ordinário, que custava em Belém mil réis, o índio dava ao regatão um pote de óleo de copaíba que valia $20 \$ 000$ réis. Por três potes de óleo (60\$000) o índio recebia uma arma de fogo ordinária que valia $5 \$ 000$. Por oito potes do mesmo óleo (160\$000) recebia um barril de pólvora que valia 17\$000 réis. ${ }^{31}$

Em seu relatório de 1875, o presidente da província do Pará, Pedro Vicente de Azevedo, dizia que o regatão

por um rosário de miçangas recebe do índio um alqueire de castanhas, por um corte de chita que vale 1.500 a 2.000, por algumas libras de pirarucu ou por um frasco de aguardente recebe um pote de óleo de copaíba, ou uma arroba de borracha. Um espelho que custa $1 \$ 000$ rende-lhe na permuta 10, 20 ou 30\$000, conforme as circunstâncias e o comprador. ${ }^{32}$

Dessa forma, ao mesmo tempo em que se construía a imagem do regatão como a personificação da cobiça, definia-se o lugar do índio nessa relação sempre no papel de vítima ingênua da ação dos "filhos da ventura". 33

\section{Perversor e civilizador dos índios}

Não demorou para que os regatões fossem considerados os principais obstáculos à catequese e civilização dos índios. Ainda em 1844, o presidente da província do Pará, Manoel Paranhos da Silva Vellozo, relatava em seu discurso que, entre as exigências feitas pelo missionário do Xingu, constava a

\footnotetext{
${ }^{31}$ Governo do Pará. Relatorio apresentado á Assembléa Legislativa da provincia do Pará na $1^{\text {a }}$ da $13^{\text {a }}$ legislatura pelo Exm. Sr. presidente da provincia, dr. Francisco Carlos de Araujo Brusque em $1^{\circ}$ de setembro de 1862. Pará: Typ. de Frederico Carlos Rhossard, 1862, p. 11.

32 Governo do Pará. Relatorio apresentado ao exm. senr. dr. Francisco Maria Corrêa de Sá e Benevides pelo exm. senr. dr. Pedro Vicente de Azevedo, por occasião de passar-lhe a administração da provincia do Pará, no dia 17 de janeiro de 1875. Pará: Typ. de F. C. Rhossard, 1875, p. 57.

33 Apesar de sugerir que "no caso das trocas entre índios e regatões, deve-se levar em consideração que ambas as partes poderiam auferir ganhos e, quando isso não acontecia e se quebrava o acordo, havia o conflito", os índios pouco aparecem nas redes de relações apontadas por Lopes em sua dissertação de mestrado. LOPES, Simeia de Nazaré. O comércio interno..., op. cit., p. 81. Para outras leituras sobre a atuação dos regatões no período áureo de exploração da borracha na Amazônia, conferir MOOG, Vianna. O ciclo do ouro negro: impressões da Amazônia. Belém: Conselho Estadual de Cultura, 1975; OLIVEIRA FILHO, João Pacheco. O caboclo e o brabo: notas sobre duas modalidades de força de trabalho na expansão da fronteira amazônica no século XIX. In: Encontros com a Civilização Brasileira, v. 11, 1979, p. 101-147; WEINSTEIN, Bárbara. A borracha na Amazônia: expansão e decadência (1850-1920). São Paulo: Hucitec/Edusp, 1993; McGRATH, David. Parceiros no crime..., op. cit., 1999.
} 
proibição de irem os regatões comerciarem diretamente com os índios devendo edificar-se uma casa no rio Tucuruí para onde eles conduzam o resultado do seu trabalho a fim de se fazer ali a permutação com os gêneros conduzidos pelas canoas de comércio e sob as vistas de uma pessoa que zele os interesses dos mesmos índios. ${ }^{34}$

Em 1849, Jerônimo Francisco Coelho, então presidente da província do Pará, reproduzia informações recebidas do missionário Egídio de Garésio, responsável pela missão do Tapajós, constituída por índios Munduruku. Dizia ele que grande parte dos índios se achava fora das aldeias, trabalhando como agregados a serviço de particulares, com os quais tinham sempre abertas "contas leoninas". Tais comerciantes davam aos índios

retalhos de más fazendas pelo quádruplo do que valem e ao mesmo tempo taxandolhes os serviços em diminutos valores, de modo que é sempre o índio quem deve; e por este título de credores perpétuos pretendem desconhecer a competência do missionário sobre os índios e recusam entregá-los, o que são outras tantas causas de contrariedade para o aumento, tranquilidade e boa ordem dos aldeamentos. ${ }^{35}$

O missionário informava que essa situação não ocorria apenas entre os Munduruku, "mas em todos os pontos da província onde há índios ou aldeados ou em suas malocas e os principais corruptores dos indígenas são essas quadrilhas de canoas de regatões, mascates ou quitandeiros dos rios". ${ }^{36}$

Em seu relatório de 1876, o presidente da província do Amazonas, Antonio dos Passos Miranda, condenava a ação dos “(...) regatões que, à semelhança de vampiros, vão abusando da ingenuidade e boa índole dos catequizados, sugando-lhes o melhor fruto de seus trabalhos, em troca de objetos de insignificante valor e de bebidas alcoólicas". Taxativo, o presidente concluía: "os regatões são os maiores inimigos da verdadeira catequese porque eles preferem o índio completamente ignorante, visto que com mais facilidade o corrompem e iludem". ${ }^{37}$

${ }^{34}$ Governo do Pará. Discurso recitado pelo Exm. Sr. desembargador Manoel Paranhos da Silva Vellozo, presidente da provincia do Pará, na abertura da $1^{\mathrm{a}}$ sessão da $4^{\mathrm{a}}$ legislatura da Assembléa Provincial no dia 15 de agosto de 1844. Pará: Typ. de Santos $\&$ menores, 1844, p. 16-17.

${ }^{35}$ Governo do Pará. Fala dirigida pelo Exm. Sr. Conselheiro Jerônimo Francisco Coelho, presidente da província do Grão-Pará à Assembléa Legislativa provincial, na abertura da $2^{\mathrm{a}}$ sessão ordinária, da $6^{\mathrm{a}}$ legislatura, no dia $1^{\circ}$ de outubro de 1849. Pará: Typ. de Santos e Filhos, 1849, p. 82.

36 Idem.

${ }^{37}$ Governo do Amazonas. Relatorio apresentado á Assembléa Legislativa Provincial do Amazonas na $1^{\text {a }}$ sessão da $13^{\text {a }}$ legislatura em 25 de março de 1876 pelo Exm. Sr. presidente da provincia, dr. Antonio dos Passos Miranda. Pará: Typ. do Diario do Gram-Pará, 1876, p. 22. 
Como forma de se contrapor à ação dos regatões, d. Macedo Costa, bispo do Pará, concebeu "(...) a ideia do Cristóforo, navio-Igreja, destinado a levar a religião aos mais recônditos dos nossos rios, na catequese dos índios e no ensino dos habitantes do interior do Estado". ${ }^{38}$ No entanto, esta "Igreja flutuante $^{\prime \prime 39}$ não chegou a ser concretizada.

Por um lado, o regatão era visto como o maior inimigo da civilização dos índios. Entretanto, no discurso de alguns presidentes da província, a imagem dos "filhos da ventura" era pintada com outros contornos. Diante do fracasso das missões na década de 1860, o presidente da província do Amazonas, Adolfo de Barros Cavalcanti de Albuquerque Lacerda, refletia: "Hoje, quem vai ao encontro do índio no fundo de suas florestas virgens, no interior destes rios sem fim? Ninguém, a não ser o regatão, menos bárbaro, por certo, que ele, porém muito mais corrompido, que o explora, deprava e desonra, a pretexto de comerciar". 40

Em 1869, um deputado identificado apenas como "Marcos", discursando na Assembleia Provincial do Pará dizia que "Há mania, Senhor presidente, em classificar os regatões de apóstolos da desmoralização e sob esse pretexto carregá-los de pesadíssimos impostos, quando é certo que são eles os únicos missionários que temos, são os verdadeiros catequistas do trabalho e da civilização dos nossos índios".41

Em 1871, o então presidente da província do Pará, Abel Graça, afirmava que "é mister confessar que ao comércio ousado do regatão devemos, sem dúvida, o descobrimento de muitas regiões até então reputadas inacessíveis, com o aumento da exportação de produtos indígenas". ${ }^{42}$

\footnotetext{
38 AMANAJÁS, Hygino. D. Antonio de Macedo Costa, bispo do Pará e arcebispo da Bahia - sua vida e suas obras. Revista do Instituto Histórico e Geográfico do Pará, ano II, fasc. II. Belém, outubro de 1918, p. 214.

${ }^{39}$ Governo do Pará. Relatório que ao Exm. Sr. Dr. João Lourenço Paes de Sousa, primeiro vice-presidente da província do Grão-Pará apresentou ao Exm. Sr. Dr. Carlos Augusto de Carvalho, ao passar-lhe a administração aos 16 de setembro de 1885. Pará: Typ. de Francisco da Costa Júnior, 1885, p. 112.

${ }^{40}$ Governo do Amazonas. Relatorio apresentado á Assembléa Legislativa da provincia do Amazonas na sessão ordinaria do $1^{\circ}$ de outubro de 1864, pelo dr. Adolfo de Barros Cavalcanti de Albuquerque Lacerda, presidente da mesma provincia. Pernambuco: Typ. de Manoel Figueiroa de Faria \& Filho, 1864, p. 36.

${ }^{41}$ [Nota avulsa]. Diário de Belém, Belém, 11 nov. 1869, p. 1.

${ }^{42}$ Governo do Pará. Relatório apresentado á Assembléa Legislativa provincial na 2a sessão da XVII Legislatura, em 15 de agosto de 1871, pelo presidente da Província Dr. Abel Graça. Pará: Typ. do Diário do Grão-Pará, 1871, p. 41-2.
} 
Mais significativo ainda foi o discurso de Pedro Vicente de Azevedo, em 1875, quando afirmou que "(...) no Pará, se conhece[m] três diversos agentes da civilização dos índios: o missionário, o regatão e o diretor parcial". ${ }^{43}$ Se, num primeiro momento, o regatão era visto como inimigo da catequese e civilização dos índios, em outro ele figura na mesma condição de missionários e diretores parciais. Azevedo vai além disso, ao afirmar que "(...) em geral, pode dizer-se que mais serviços tem feito à civilização a cobiça imoral do regatão do que a moralidade fria e doutrina religiosa do missionário". ${ }^{44}$

Para muitos, a solução seria regularizar a atividade e sobrecarregar as canoas de regatão com mais impostos, além de reforçar a fiscalização. Afinal, o desconforto com a atividade não se dava necessariamente pelos prejuízos dos índios, mas sim pelos prejuízos do governo, que não tinha estrutura para garantir a coleta de impostos dos comerciantes e pela concorrência que os regatões faziam aos comerciantes dos povoados.

Sempre que proibiam os índios de entrar em contato com "gente civilizada", a fim de livrá-los da ação dos regatões, os missionários se tornavam alvo das críticas dos comerciantes. Foi o que aconteceu com o frei Pelino de Castrovalva, responsável pela missão do Tapajós. Ao se colocar no papel de intermediário entre os Munduruku e os comerciantes, atraiu para si o ódio dos regatões da região, que organizaram um jornal para difamá-lo, acusando-o de explorar os índios e de manter uma amante indígena. Segundo relato do capuchinho, por diversas vezes ele foi ameaçado de morte pelos regatões ${ }^{45}$ que utilizavam contra o missionário o mesmo discurso de cobiça desenfreada do qual eram vítimas constantes.

Criticando o "sistema atual de missões", Pedro Vicente de Azevedo afirmava que

(...) quase se é tentado a dizer, ainda que com grande repugnância: enquanto se não melhorar o sistema atual de missões, devemos pedir a Deus que multiplique a praga dos regatões, porque de sua coragem insolente, da sua cobiça desenfreada, de suas empresas afoitas, resulta sempre algum bem mais real e permanente do que o das missões atuais. ${ }^{46}$

43 Governo do Pará. Relatorio apresentado..., op. cit., 1875, p. 56.

${ }^{44}$ Idem

${ }^{45}$ CASTROVAlVA, frei Pelino de. O rio Tapajós, os capuchinhos e os índios Mundurucus (1871-1883). São Luís, Maranhão, 2000 [1884].

${ }^{46}$ Governo do Pará. Relatorio apresentado..., op. cit., 1875, p. 59. 
O regatão seria uma espécie de mal que vem para o bem, pois através de sua audácia muitos povos indígenas teriam sido contatados, sendo estimulados ao trabalho da extração das "drogas do sertão" e também ao comércio. Não à toa, Darcy Ribeiro definiu o regatão como "criador de necessidades e instrumento de sua satisfação". ${ }^{47}$

$\mathrm{O}$ regatão chegava muito mais longe que qualquer outro agente da civilização. Segundo a linguagem figurada do presidente da província do Pará, Pedro Vicente de Azevedo, a ação deste "rei do igarapé" estendia-se "(...) do sertão até à capital, abrindo, por assim dizer, a machado o caminho da civilização, mas infeccionando-lhes as margens com os germens que esparge a cada passo, de sua corrupção e conduta reprovada". ${ }^{48}$ Em seu nomadismo fluvial, cruzava ao longo de seu sinuoso caminho nos rios e igarapés da Amazônia com casas de gente tida por civilizada, choupanas de tapuios, barracas de seringueiros, ranchos de mocambeiros e/ou desertores e mesmo com povos indígenas considerados "selvagens".

\section{O feitiço contra o feiticeiro}

Conforme dito mais acima, o índio figura na relação com os regatões sempre na condição de vítima ingênua. Ao explicar o modo de funcionamento do comércio entre índios e regatões, o presidente da província do Pará, Antonio Coelho de Sá e Albuquerque, dizia que tal comércio "consiste quase sempre na permuta de aguardente e de objetos de insignificante valor por objetos de grande preço fabricados ou colhidos pelos índios". ${ }^{49} \mathrm{Um}$ ano antes, o viajante alemão Robert Avé-Lallemant relatou o que ouviu em Santarém sobre o comércio no Tapajós, em que os comerciantes de Mato Grosso trocavam couros de boi e sal "enquanto os índios vêm com guaraná, que trocam por bugigangas, ou trazem salsaparrilha para o mercado". 50

\footnotetext{
${ }^{47}$ RIBEIRO, Darcy. Os índios e a civilização: a integração das populações indígenas no Brasil moderno. Petrópolis: Vozes, 1979, p. 26.

${ }^{48}$ Governo do Pará,. Relatorio apresentado..., op. cit., 1875, p. 56.

${ }^{49}$ Governo do Pará. Relatório que o Exm. Sr. Dr. Antonio de Sá e Albuquerque, presidente da Província do Pará apresentou ao Exm. Sr. vice-presidente, Dr. Fábio Alexandrino de Carvalho Reis, ao passar-lhe a administração da mesma província em 12 de maio de 1860. Pará: Typologia comercial de Antonio José Rabelo Guimarães, p. 32.

${ }^{50}$ AVÉ-LALLEMANT, Robert. Viagem pelo norte do Brasil no anno de 1859. Rio de Janeiro: Ministério da Educação e Cultura, 1961 [1860], p. 75.
} 
Esta mesma imagem dos índios pode ser constatada em 1862, no relatório de Francisco Carlos de Araújo Brusque. Para este presidente, "a vontade do regatão é a lei, que rege, enquanto ele ali permanecer pelo tempo necessário a seus negócios. E o pobre índio lhe obedece cegamente!". ${ }^{51}$ A sedução pelos objetos da cultura material não-indígena tornava, segundo o presidente, os índios completamente sujeitos ao império dos regatões. Antonio dos Passos Miranda, presidente da província do Amazonas, afirmava que "Ignorantes, dóceis por índole, tornam-se os índios verdadeiros autômatos dos regatões e, inanidos, não se opõem à operação da pilhagem e, ainda mais, veem, impassíveis, o sexo frágil, mesmo em idade infantil, ser arrastado para servir à concupiscência daqueles indivíduos". ${ }^{52}$

Atribuía-se boa índole aos índios, mas esta característica era apontada como algo que facilitava sua ludibriação pelos regatões. Ao passo que estes são sempre definidos como espertos, gatunos, astuciosos, os índios geralmente são descritos como ingênuos, ignorantes, autômatos, incapazes de reagir aos desmandos dos regatões.

Tal como no período colonial, nota-se a mesma explicação atribuída ao chamado escambo, em que os índios seriam sempre lesados por oferecerem produtos de alto valor monetário e, em troca, receberem "objetos de insignificante valor", as tais bugigangas ou quinquilharias. ${ }^{53}$ Darcy Ribeiro dizia que a principal atividade do regatão consistia na "exploração do índio, que trabalha o ano inteiro juntando a copaíba, a castanha, a canela, o cravo, a salsaparrilha, a piaçava, para trocar por pouco mais que nada". ${ }^{44}$ Ainda no século XX, ao se referir ao comércio na Amazônia colonial, Bárbara Weinstein dizia que, em troca de produtos exóticos, "os trabalhadores recebiam dos comerciantes ou missionários portugueses ferramentas, roupas, as bugigangas costumeiras (...)".55

Leitura mais atenta da documentação que registra a experiência de trocas entre índios e regatões aponta para outras nuances que podem retirar os índios dessa condição de passividade que lhes foi imposta pelas autoridades das províncias e, em grande medida, incorporada pela historiografia. É preciso lembrar que essa documentação foi escrita por não-índios, devendo

${ }^{51}$ Governo do Pará. Relatorio..., op. cit., 1862, p. 13.

${ }^{52}$ Governo do Amazonas. Relatorio..., op. cit., 1876, p. 22.

53 REIS, Arthur Cezar Ferreira. O seringal e o seringueiro. Rio de Janeiro: Ministério da Agricultura, 1953, p. 124.

${ }^{54}$ RIBEIRO, Darcy. Os índios e a civilização..., op. cit., 1979, p. 26-27.

55 WEINSTEIN, Bárbara. A borracha na Amazônia..., op. cit., 1993, p. 24. 
ser lida com certo cuidado. De todo modo, exatamente por isso ela merece atenção, eis que diversas situações revelam as atitudes de enfrentamento dos índios diante dos regatões, mesmo quando o que se pretendia era apresentá-los como vítimas passivas.

Em seu relatório de 1863, o presidente da província do Pará, Francisco Carlos de Araújo Brusque, descreveu as "relações de amizade e comércio" entre os índios Urupaya e Tucunapeua. Dizia ele que estes últimos frequentemente se encontravam com as caravanas de comerciantes que subiam o rio Xingu em busca de produtos naturais. Destes regatões recebiam "alguns objetos que fornecem aos Urupaya em troca de canoas, fio, algodão, redes e galinhas". ${ }^{56} \mathrm{O}$ presidente acrescentou uma informação que serve de indicativo da maneira como determinados grupos indígenas lidavam com as mercadorias que recebiam dos regatões: "intermediários nesse fornecimento, os Tucunapeua fazem seus vizinhos pagar mais caros os objetos que lhes vendem e que consistem principalmente em ferramentas de lavoura e miçangas, que muito apreciam para seus enfeites". ${ }^{57}$

A informação fornecida pelo presidente da província constitui indício importante de certa leitura indígena das relações de comércio estabelecidas com os regatões e entre si. De alguma forma, os Tucunapeua reproduziam, na relação com outros grupos indígenas, os mecanismos de funcionamento de suas trocas com os regatões, procurando tirar vantagens em cima dos bens que recebiam destes comerciantes. ${ }^{58}$ Por outro lado, nota-se a existência de certa especialização entre os índios, eis que nem todos os grupos produziam as mesmas coisas, o que servia de incentivo ao comércio interétnico.

\footnotetext{
${ }^{56}$ Governo do Pará. Relatório apresentado a Assembléa Legislativa da província do Pará, na $2^{\text {a }}$ sessão da $13^{\text {a }}$ legislatura pelo Exm. Sr. Presidente da província Dr. Francisco Carlos de Araújo Brusque, em 1 de novembro de 1863. Pará: Typ. de Frederico Carlos Rhossard, 1863, p. 17.

57 Idem, p. 18.

${ }^{58}$ Analisando o caso dos índios Deni do rio Cuniuá, no Amazonas atual, Florido observou que “ao estabelecerem relações com um patarahu [corruptela do termo 'patrão' em português], os indígenas obtinham mercadorias a crédito e contraíam dívidas que posteriormente eram pagas com produtos da atividade extrativista. Por sua vez, aqueles indígenas que obtiveram os manufaturados podiam servir de intermediários com os moradores das aldeias, reproduzindo a forma de relação entre os patrões e os empregados". FLORIDO, Marcelo Pedro. O manakuni dos Deni: prestações e contraprestações no rio Cuniuá (AM). In: AMOROSO, Marta E SANTOS, Gilton Mendes dos. Paisagens ameríndias: lugares, circuitos e modos de vida na Amazônia. São Paulo: Terceiro Nome, 2013, p. 275-298, p. 78. Uma observação feita pelo autor faz toda a diferença: em se tratando de trocas entre os próprios Deni, é necessário que o pagamento, isto é, a retribuição, seja tida como equivalente à coisa dada, sem acréscimo em relação ao valor do que foi pago.
} 
Graças à posse de ferramentas e miçangas que tanto os Urupaya apreciavam, os Tucunapeua obtinham destes canoas, fio, algodão, redes e galinhas. Ao reinserirem os objetos que recebiam dos regatões no circuito de trocas tradicional com outros grupos indígenas, os Tucunapeua evidenciam que a presença de objetos não-indígenas nas aldeias não serve de indicativo de nenhum tipo de grau de "pureza" ou de "perda" da identidade indígena. Afinal, nem todos os objetos da cultura material dos não-índios permaneciam nas aldeias. No caso citado, nota-se que mesmo mercadorias altamente valorizadas, tais como ferramentas de lavoura e miçangas, poderiam ser reinseridas no circuito de trocas, de modo a satisfazer finalidades tradicionais.

Deparando-se com diademas entre índios em uma aldeia do rio Uapés, relatou Wallace: "perguntei-lhes de que eram feitos os diademas e eles responderam que os compravam dos índios do Japurá e de outros rios, pagando caro por tais adornos, pois três ou quatro pecinhas custavam um machado!". ${ }^{59}$ Note-se que o valor de mercado atribuído pelos brancos ao machado de ferro pouco significava diante do valor de uso que os índios atribuíam aos tradicionais diademas. Conforme demonstrou John Monteiro ${ }^{60}$ referindo-se ao período colonial, essa situação geraria um paradoxo: ao estabelecerem relações de troca visando a satisfação de finalidades tradicionais, os índios adotavam postura ostensivamente conservadora. No entanto, ao fazer isso, contribuíam cada vez mais para a transformação acelerada das relações interétnicas e entre índios e colonos.

Em outro exemplo, ao observar o uso que os índios Manetenery faziam de contas vermelhas nos pulsos, o engenheiro João Martins da Silva Coutinho afirmou que, "provavelmente são os regatões da Bolívia que fornecem as contas aos índios dos afluentes do Beni e estes, por sua vez, negociam com os Manetenery". ${ }^{61}$ Em todos os casos citados, os objetos eram reprocessados de modo a fortalecer antigas alianças interétnicas e, ao mesmo tempo, permitir acesso a objetos produzidos ou adquiridos por outros grupos indígenas. ${ }^{62}$

59 WALLACE, Alfred Russel. Viagens pelos rios Amazonas e Negro. Belo Horizonte: Itatiaia; São Paulo: Edusp, 1979 [1853], p. 186.

${ }^{60}$ MONTEIRO, John Manuel. Negros da terra: índios e bandeirantes nas origens de São Paulo. São Paulo: Companhia das Letras, 1995, p. 32.

${ }^{61}$ Brasil. Ministério da Agricultura. Relatório..., op. cit., 1865, anexo O, p. 77.

${ }^{62}$ Estando a serviço de regatões ou viajantes, os índios procuravam se abastecer com mercadorias valorizadas por outros grupos, como o fizeram os que acompanharam Wallace numa parada em Breves: "alguns de nossos índios desceram, enquanto nós preferimos ficar a bordo esperando a maré. Eles voltaram um tanto ou quanto embriagados, trazendo consigo diversos 
Em outras situações, é possível perceber que, muito embora pudessem ser prejudicados em determinadas transações, ofertando mais do que recebiam, os índios possuíam certos parâmetros na negociação com os regatões. Dizia Adolpho de Barros Cavalcanti de Lacerda, presidente da província do Amazonas, que os índios Manetenery "têm em grande estimação os panos que fabricam e que os seringueiros do baixo Purus compram por $1 \$$ a vara para fazer redes e só o trocam por instrumentos e utensílios de ferro, de que são muito cobiçosos". ${ }^{63}$ A informação de que os Manetenery só trocavam os panos que fabricavam por instrumentos de ferro constitui indício bastante significativo do valor que eles atribuíam a este produto, bem como de sua percepção do quanto tais panos despertavam interesse nos regatões, a ponto de servirem de moeda de troca pelos cobiçados instrumentos de ferro. Estavam longe, portanto, da imagem de "autômatos dos regatões".

A mesma percepção da posse de um produto bastante cobiçado pode ser atribuída aos "Maué, que cultivam o guaraná, que hoje faz a riqueza do município deste nome e os Munduruku, que igualmente plantam o guaraná (...)". ${ }^{64}$ Os Maué recebiam comerciantes de diversas partes da região, inclusive do Mato Grosso, o que lhes garantia oferta e circulação permanente de produtos em suas aldeias. ${ }^{65}$ Muito embora nem sempre as trocas fossem simétricas, certamente este comércio era útil tanto para os regatões quanto para os indígenas.

Em várias situações, os índios partiram para o enfrentamento direto e violento dos regatões. São recorrentes os relatos de agressões ou mesmo assassinatos cometidos por índios. Em 1844, Manoel Paranhos da Silva Vellozo

bules de cerâmica em formato de pombas, muito valorizados nos trechos situados rio acima". WALLACE, Alfred Russel. Viagens pelos rios..., op. cit., 1979 [1853], p. 91.

${ }^{63}$ Governo do Amazonas. Relatorio com que o illustrissimo e Exc. Sr. dr. Adolpho de Barros Cavalcanti de A. Lacerda entregou a administração da provincia do Amazonas ao illm. e exm. sr. tenente coronel Innocencio Eustaquio Ferreira de Araujo. Recife: Typ. do Jornal do Recife, 1865, p. 33.

${ }^{64}$ A consulta a este relatório foi feita no endereço http://brazil.crl.edu/bsd/bsd/u094/, em 11 de março de 2014. Infelizmente, o relatório está incompleto, faltando, inclusive, as informações sobre data da sessão e nome do presidente da província. A citação é da página 333.

${ }^{65}$ Gonçalves Tocantins revelou a forma como os Maué, muito embora fazendo parte de um circuito que agenciava para fora da aldeia um produto de consumo tradicional (o guaraná), procuravam imprimir nesse negócio sua marca cultural distintiva: "geralmente o preparam em forma de pão cilíndrico; outras vezes, porém, moldam-nos sob forma de animais da fauna dessas regiões, tais como antas, serpentes, tartarugas e outros, trabalhando neste artefato com notável inteligência e gosto artístico". Dessa forma, articulavam novas relações de contato com a realização de finalidades tradicionais. TOCANTINS, Antonio Manuel Gonçalves. Estudo sobre a tribu Mundurucu. Revista Trimensal do Instituto Histórico Geographico e Ethnographico Brasileiro, tomo XL. Rio de Janeiro: B. L. Garnier, 1877, p. 146. 
informava que alguns regatões "já têm sido vítimas da indignação dos índios, como não há muito tempo sucedeu no rio Juruá, onde foram assassinados dois destes traficantes por não pagarem os objetos que lhes compravam usando, além disso, para com eles violência, prendendo-os e até vendendo-os (...)".66

Em 1852, na província do Amazonas, dois comerciantes navegavam para o Mato Grosso quando "foram assaltados pelos gentios da tribo Caripuna, vendo-se obrigados a desampararem as suas canoas com todas as mercadorias, fugindo em uma montaria com o piloto que, tendo desembarcado, foi recebido com quatro flechadas, chegando em Borba em perigo de vida". ${ }^{67}$ Em outubro de 1861, sete índios Tembé da aldeia Traquateua, no alto Gurupi, cansados dos maus tratos e dos raptos constantes de suas mulheres, assassinaram alguns regatões como forma de vingança. ${ }^{68}$

Em Santarém, o regatão Manoel Quirino Paes foi assassinado pelo índio José Apiacá em 1871. Paes era mulato e, inicialmente, trabalhava como remeiro de canoas de regatões. Abandonando esse serviço, fixou moradia no rio Tapajós, próximo à missão do Bacabal, utilizando os índios Munduruku na extração da borracha. Relatou Gonçalves Tocantins que "tornado assim opulento, o mulato trazia os índios em verdadeiro e rigoroso cativeiro. Ai daquele que tentasse ausentar-se de sua feitoria".69 Uma índia Maué chamada Francisca tentou fugir duas vezes, sendo sempre capturada e castigada. Por fim, resolveu se vingar, associando-se a um índio Apiacá, a quem entregou uma espingarda utilizada para assassinar seu patrão. Os dois índios foram presos e levados ao júri em Santarém. Diante do júri, “Francisca Maué declarou-se única autora do crime. Erguendo a curta saia perante o tribunal, mostrou as pernas ainda com os vestígios dos ferros que por longo tempo sofrera", ${ }^{70}$ relatando toda a violência sofrida por ela e suas companheiras de infortúnio. Francisca Maués foi absolvida, mas José Apiacá foi condenado e enviado para a Bahia, onde deveria pagar sua pena.

Apesar de inúmeros exemplos de enfrentamento dos índios diante dos regatões, a historiografia cristalizou a imagem do índio enquanto ingênuo

\footnotetext{
${ }^{66}$ Pará. Discurso recitado..., op. cit., 1844, p. 17.

${ }^{67}$ Governo do Amazonas. Falla dirigida á Assembléa Legislativa da provincia do Amazonas, na abertura da $1^{\text {a }}$ sessão ordinária da $1^{\text {a }}$ legislatura, pelo Exm. vice-prezidente da mesma provincia, o dr. Manoel Gomes Correa de Miranda, em 5 de setembro de 1852. Capital do Amazonas: Typ. de M. da S. Ramos, 1852, p. 5.

${ }^{68}$ Governo do Pará. Relatorio..., op. cit, 1862, p. 13.

${ }^{69}$ TOCANTINS, Antonio Manuel Gonçalves. Estudo sobre a tribu Mundurucu..., op. cit., 1877, p. 157.

${ }^{70}$ Idem, p. 158.
} 
e vítima passiva. Para Arthur Cezar Ferreira Reis, "as tribos opuseram a resistência que puderam. Essa resistência, de resultados passageiros, momentânea. Porque ao fim se viram sempre obrigadas a ceder. Tribos e tribos, nos contatos sangrentos, desapareceram ou reduziram-se".71 Em "O regatão", Mário Ypiranga Monteiro dedica não mais que duas páginas para demonstrar que os índios "vingavam-se dessa tenaz exploração, não raro, fugindo aos patrões" e que, "às vezes tomavam desforços cruéis", 72 quando assassinavam os regatões. José Alípio Goulart cita alguns poucos exemplos da "resistência desesperada e tenaz do inconformado ameríndio". ${ }^{73}$

"Vingança" e "resistência desesperada" são termos que descaracterizam a ação dos índios como sujeitos, ao colocá-los sempre na condição de reação frente a uma ação inicial atribuída aos regatões. Assim, José Alípio Goulart se refere ao "habitante, o selvagem, de cultura recuadíssima no tempo, acossado, maltratado, exterminado, escravizado pelo invasor, expulso do seu habitat, transbordante de ódio e de ressentimento para com o branco".74 Dessa forma, as "reações" indígenas seriam sempre resultado de sua "resistência desesperada", "de ódio e de ressentimento", o que corrobora a visão do índio como elemento que faz parte da natureza, sendo sua reação entendida como natural, biológica, nunca como ação política consciente..$^{75}$

Para concluir este tópico, apresentamos um episódio que, a nosso ver, é o mais significativo quanto ao papel ativo desempenhado pelos índios na relação com os regatões. João Martins da Silva Coutinho, em seu relatório de exploração ao rio Purus, se refere a Apucaham, principal dos índios Pammary, nos seguintes termos:

\footnotetext{
${ }^{71}$ REIS, Arthur Cezar Ferreira. O seringal e o seringueiro..., op. cit., 1953, p. 128.

${ }^{72}$ MONTEIRO, Mário Ypiranga. $O$ regatão..., op. cit., 1958, p. 60-61.

${ }^{73}$ GOULART, José Alípio. 0 regatão..., op. cit, 1968, p. 81.

${ }^{74}$ Idem, p. 30.

${ }^{75}$ No mesmo sentido, Goulart explica a preponderância dos índios como guias e remeiros dos regatões em função de seu "instinto atávico" que, "aliado à experiência sedimentada pelo cotidiano sobre as águas, substituindo no homem amazônico qualquer elaboração mental necessária à utilização de instrumental apropriado". GOULART, José Alípio. O regatão..., op. cit., 1968, p. 72. O conhecimento indígena é relegado a uma questão de "instinto", negando-se a experiência de produção de conhecimento dos índios a partir de sua interação com a natureza.
} 
Apucaham por diversas vezes enganou alguns regatões, dando em troca de fazendas e ferramentas, tartarugas magras, que não compensavam a importância dos gêneros da maneira porque lá são elas vendidas.

Era a compensação, talvez, de outras transações infelizes que houvesse feito. ${ }^{76}$

Note-se que Apucaham aprendeu a dinâmica das negociações com os regatões, utilizando contra estes suas próprias práticas para conseguir vantagens nas relações de troca. Atitudes como a deste índio podem ser encontradas em outras partes da Amazônia. Referindo-se às trocas realizadas entre regatões e índios do rio Gurupi, Gustavo Dodt questionava: "e pode-se admirar que o índio, vendo que a gente que se diz civilizado, faz tudo para se enganar e iludir entre si, siga pela pista dos que sempre considera como intrusos?".77 Certamente Apucaham presenciou inúmeras situações de deslealdades entre os regatões que atuavam no rio Purus, além daquelas situações em que ele mesmo foi envolvido.

O episódio é ainda mais significativo porque tudo indica que João Martins da Silva Coutinho obteve esta informação do próprio Apucaham. Note-se que o engenheiro não diz apenas que as tartarugas magras não compensavam a importância dos gêneros ofertados pelos regatões. Ele diz que as tartarugas magras não compensavam a importância dos gêneros "da maneira porque lá são elas vendidas". Ou seja, o costumeiro era os índios oferecerem sempre mais do que aquilo que recebiam. Ao agir assim, trocando tartarugas magras por tecidos e ferramentas que valiam muito mais, Apucaham literalmente usava o feitiço contra o feiticeiro.

\section{A dimensão simbólica das trocas}

Referindo-se às viagens dos regatões pelo Alto Tapajós, Gonçalves Tocantins dizia que

aí não encontram com quem comerciar, a não ser os Munduruku e alguns poucos Maué selvagens, que andam nus ou seminus, não têm a menor noção da nossa língua, nem

${ }^{76}$ Brasil. Ministério da Agricultura. Relatório..., 1865, anexo O, p. 72.

77 DODT, Gustavo. Descrição dos rios..., op. cit., 1981, p. 96. 
do nosso alfabeto, nem do nosso sistema de pesos e medidas, nem dos preços correntes dos gêneros que vendem, nem das mercadorias que compram. ${ }^{78}$

Por esse ponto de vista, é fácil entender que os índios eram, muitas vezes, "enganados". Prossegue Tocantins: "quando se pergunta a estes índios quanto devem, respondem sempre: 'quem sabe! Só o patrão é que pode saber!'"79 $\mathrm{O}$ autor também apresenta duas contas correntes entre índios e regatões, demonstrando como as mercadorias foram vendidas aos índios com lucros de 400 por cento. ${ }^{80}$

Há que se destacar, também, o uso que os regatões faziam de outro instrumento no processo de convencimento dos índios: a cachaça. Em "Selvagens bebedeiras" João Azevedo Fernandes discutiu o significado das bebidas alcoólicas para os grupos indígenas. Segundo o autor, devem-se pensar as bebidas entre os índios como "um sistema cultural". As formas nativas de experiência etílica constituíam espaço crucial para a expressão de suas visões de mundo e para a realização de eventos e práticas centrais em suas culturas. Nesse sentido, as festas tradicionais indígenas, as "cauinagens",

também possuem um caráter ritual e dramático, no qual performances de canto e dança, juntamente com exibições oratórias e excessos etílicos são usados para articular relações sociais e cosmológicas, reafirmar diferenças de idade e gênero e construir relações de amizade e inimizade. ${ }^{81}$

Dessa forma, as festas indígenas exerciam papel social muito mais importante do que a simples diversão. O consumo de cachaça que os índios faziam junto aos regatões ocorria pari passu ao processo de extinção ou desvalorização simbólica das bebidas tradicionais indígenas, abrindo espaço "para a criação de um espaço de ebriedade que superava em muito os limites da antiga embriaguez cerimonial". ${ }^{2}$

78 TOCANTINS, Antonio Manuel Gonçalves. Estudo sobre a tribu Mundurucu..., op. cit., 1877, p. 147.

${ }^{79}$ Idem, p. 148. Em pesquisa recente, Florido constatou que "perguntando para um Deni recémchegado da cidade qual o preço de algo que comprou, isto é, qual o seu manakuni, é comum obter como resposta: não perguntei, fiquei devendo. FLORIDO, Marcelo Pedro. O manakuni dos Deni..., op. cit., 2013, p. 298. O termo manakuni é traduzido por estes índios como pagamento, mas, como demonstra o autor, não há correspondência exata com nossa noção de pagamento.

${ }^{80}$ TOCANTINS, Antonio Manuel Gonçalves. Estudo sobre a tribu Mundurucu..., op. cit., 1877, p. 150-154.

${ }^{81}$ FERNANDES, João Azevedo. Selvagens bebedeiras: álcool, embriaguez e contatos culturais no Brasil colonial (séculos XVI-XVII). São Paulo: Alameda, 2011, p. 96.

${ }^{82}$ Idem, p. 205. 
De acordo com José Alípio Goulart, a cachaça

constituía-se em inestimável auxiliar do regatão, eliminando os óbices, aplainando o terreno, predispondo o comprador a inconcebíveis larguezas nas aquisições e, do mesmo passo, privando-o de discernimento e inutilizando-o para o exercício da fiscalização concernente à utilidade e ao preço do que comprava e do que pagava. ${ }^{85}$

Certamente que este "auxiliar do regatão" também era utilizado nas relações com os caboclos e quilombolas da região. Afinal, o efeito das "bebidas espirituosas" não difere entre índios, brancos ou negros. Diz Goulart que o regatão "conquista num átimo o caboclo ignorante e bisonho; convence o índio inocente e arredio; engambela o negro escravo fugido, temeroso e assustado; conquista a mulher faceira e revoltada". ${ }^{84}$

A percepção da cachaça como elemento que priva o índio de discernimento e o inutiliza para o exercício da fiscalização relativiza a ideia de que ele era enganado por ser ingênuo. $\mathrm{O}$ fato de o regatão recorrer à cachaça serve de indicativo de sua percepção de que, sóbrios, seria mais difícil enganar os índios ou indivíduo de qualquer outro grupo social com quem ele mantivesse contato. Sob efeito do álcool, qualquer pessoa pode ser mais facilmente enganada.

Aliado à cachaça, o regatão fazia uso de uma performance impressionante e eficaz diante de seus fregueses. Ao aproximar-se de um lugar, anunciava sua chegada com o toque de búzio ou com tiros de espingarda. Ouvido o sinal, os moradores corriam apressados ao encontro do mercador que, de pé, à proa da embarcação, os saudava com os braços erguidos, tendo, na boca, largo e amigável sorriso, abanando no ar o seu chapéu de panamá. Encostado o barco e, com a plateia disposta, começava a apresentar as mercadorias acondicionadas em caixas, sacos, latas, fardos e pacotes, "embasbacando os circunstantes". ${ }^{85}$ Diante da mais leve demonstração de resistência à exorbitância dos preços, o regatão recorria à oferta gratuita de goles de cachaça. De acordo com Goulart,

quem, por curiosidade, penetrasse no caixão de uma galeola, ficaria abismado e aturdido diante da variedade incrível de artigos e mercadorias ali recolhidos, uns acondicionados

${ }^{85}$ GOULART, José Alípio. O regatão..., op. cit., 1968, p. 49.

${ }^{84}$ Idem, p. 49.

${ }^{85}$ Idem, p. 49. 
em prateleiras, outros espalhados pelo chão, ocupando todo o espaço disponível no interior do barco-armazém. ${ }^{86}$

Imagine-se o encantamento que o "caixão" do regatão (espaço coberto da embarcação) promovia em pessoas que habitavam longínquas povoações da Amazônia, cujo acesso a tais mercadorias por outras vias era praticamente impossível. Com relação aos índios, sabe-se do verdadeiro fascínio que lhes causaram os objetos da cultura material não-indígena. Referindo-se aos Munduruku, Murphy \& Murphy afirmaram que "o motivo básico dos movimentos migratórios para as regiões do baixo Madeira e Tapajós parece ser o desejo dos índios de obterem artigos manufaturados, especialmente utensílios de ferro". ${ }^{87}$ Outro exemplo bastante significativo desse fascínio é o que foi relatado por Bates, acerca dos índios Cucama, da Amazônia peruana:

a primeira coisa que eles se esforçam por adquirir, quando descem o rio e entram no Brasil - que todos os indígenas peruanos consideram um país mais rico do que o seu - é um baú de madeira com cadeado e chave. Nesse baú eles guardam cuidadosamente todo o dinheiro que ganham, convertido em roupas, machadinhas, facas, pontas de arpão, agulhas, linhas etc. ${ }^{88}$

Bates explicou que, em razão do pouco que recebiam em pagamento por seu trabalho, os índios levavam muito tempo para encher o baú. Talvez isso explique o fato de que os Cucama com os quais o viajante conversou estavam há 15 meses longe de suas famílias.

Pesquisas atuais entre os índios brasileiros revelam a continuidade de um modo específico destes povos encararem as relações comerciais com os não-índios. Bonilla cita, por exemplo, o caso dos Paumari, que trabalhavam para vários patrões na coleta da borracha, até meados do século XX, e, em troca de sua fidelidade enquanto fregueses, recebiam proteção em caso de perigo ou doença, além de bens simbólicos como nomes não-indígenas e laços de parentesco fictícios via relações de compadrio. Diz a autora que a “aparente submissão e autovitimização também pode ser vista como uma

\footnotetext{
${ }^{86}$ Idem, p. 50.

${ }^{87}$ MURPHY, Robert F.; MURPHY, Yolanda. As condições atuais dos Munduruku. Belém: Inst. de Antrop. e Etnologia do Pará, 1954, p. 10.

${ }^{88}$ BATES, Henry Walter. O naturalista no rio Amazonas. Belo Horizonte: Itatiaia; São Paulo: Edusp, 1979 [1863], p. 194.
} 
forma de controle e poder sobre o Outro. ${ }^{89}$ Florido, por sua vez, cita o caso dos Deni, para quem

o acesso constante às mercadorias e às potências do mundo não indígena parece ser o que de fato está por trás da relação com os patrões e isto é obtido através da manutenção de uma dívida. Entregar produtos da atividade extrativista é uma forma de agradar a essa potência perigosa e instalar a troca. ${ }^{90}$

Segundo relatos colhidos pelo autor, num primeiro momento há um grande esforço para entregar enormes quantidades de produtos em troca de pouquíssimas mercadorias. Esclarece o autor que

a língua Deni já incorporou as partículas "deve" e "paga" usadas no contexto das relações comerciais, mas pagar uma dívida, no contexto interétnico, não está associado ao seu término, e sim à possibilidade de continuar endividado. Paga-se para poder continuar devendo, e, assim, manter o fluxo de bens. ${ }^{91}$

Situação semelhante foi encontrada por Catherine Howard entre os Waiwai, que consideram "importante que algumas dívidas fiquem em aberto de ambos os lados, pois é isso que une os parceiros, apesar da distância que os separa".92

Para o século XIX, temos o relato de Bates que, diante da dificuldade de conseguir pilotos e remadores indígenas no rio Tapajós, afirmou que "é impossível encontrar um índio ou mestiço que não esteja devendo dinheiro ou trabalho a alguma autoridade ou negociante local".93 Bates afirmou que, ao chegar às aldeias dos Munduruku, habitantes das campinas no rio Tapajós, os mercadores "têm de distribuir primeiro as suas mercadorias - roupas de algodão ordinário, machados de ferro, artigos de cutelaria, miudezas e cachaça - entre os subchefes, e depois esperar três ou quatro meses pelo pagamento em forma de produtos agrícolas". ${ }^{4}$ Dessa forma, as trocas seguiam o padrão tradicional indígena, sem uso de dinheiro e submetidas ao ritmo

${ }^{89}$ BONILLA, Oiara. Cosmologia e organização social dos Paumari do médio Purus (Amazonas). Revista de Estudos e Pesquisas, v. 2. Funai. Brasília, nº 1, jul. 2005, p. 7-60, p. 49.

${ }^{90}$ FLORIDO, Marcelo Pedro. O manakuni dos Deni..., op. cit., 2013, p. 281.

${ }^{91}$ Idem, p. 283.

${ }^{92}$ HOWARD, Catherine. A domesticação das mercadorias: estratégias Waiwai. In: ALBERT, Bruce (org.). Pacificando o branco: cosmologias do contato no norte-amazônico. São Paulo: Editora Unesp; Imprensa Oficial do Estado, 2002, p. 49.

93 BATES, Henry Walter. O naturalista..., op. cit., 1979, p. 160.

${ }^{94}$ Idem, p. 181. 
de contraprestação determinado pelos próprios índios. Por outro lado, Bates indica uma série de situações em que os índios recebiam adiantado e depois desapareciam sem prestar o serviço combinado.

Estes exemplos servem de indicativo de que os índios têm uma percepção bastante distinta do que entendemos por comércio ou troca. Existe entre eles a noção de que os não indígenas são poderosos e, ao mesmo tempo, perigosos e que é possível domesticá-los, pacificá-los, através da posse de suas mercadorias. ${ }^{95}$ Do ponto de vista dos índios, existe toda uma dimensão simbólica permeando as trocas de objetos com os não indígenas, trocas que podem servir não somente para ter acesso a suas mercadorias, mas também para firmar alianças, obter proteção ou controlar a agressividade de seus produtores. ${ }^{96}$

Por outro lado, os índios escolhem o tipo de objetos da cultura material não indígena que querem em suas aldeias. Conforme relatou Avé-Lallemant, em 1859, os índios "adotaram da civilização tudo o que lhes é cômodo, com exclusão do que implica qualquer processo de trabalho". ${ }^{97} \mathrm{O}$ viajante pretendia, com isso, reforçar sua impressão de que os índios eram indolentes. Mas é possível inferir dessa citação os critérios que pautavam as escolhas feitas pelos índios, escolhendo na cultura dos não-índios aquilo que poderia tornar sua vida mais cômoda. Referindo-se aos índios habitantes do rio Gurupi, Gustavo Dodt afirmava que "pela introdução de utensílios de ferro e de aço tem-se tornado o trabalho mais suave para os índios".98

De alguma forma, os índios avaliavam que valia a pena se submeter ao tipo de trabalho exigido pelo contato com os regatões. De acordo com Hemming,

os índios avaliavam um objeto por sua utilidade e pelo esforço despendido em sua fabricação. Sem dúvida, ignoravam o valor de mercado de itens como espingardas, pólvora, machados ou facas. Esses artigos ultrapassavam sua capacidade manufatureira,

\footnotetext{
${ }^{95}$ HOWARD, Catherine. A domesticação das mercadorias..., op. cit, 2002, p. 25-60. Diversos povos indígenas fazem associação entre objetos manufaturados e doenças dos brancos. Os Yanomami, por exemplo, com medo das doenças originadas da "fumaça do metal", lavavam as mercadorias recebidas com lama e areia, deixando-as por algumas horas mergulhadas num riacho, a fim de serem purificadas. ALBERT, Bruce. A fumaça do metal: história e representações do contato entre os Yanomami. Anuário Antropológico 89. Rio de Janeiro: Tempo Brasileiro, 1992, p. 166.

${ }^{96}$ John Monteiro já havia destacado, com relação aos índios de São Paulo colonial, que "cabe ressaltar que o escambo ganha sentido apenas na medida em que se remete à dinâmica interna das sociedades indígenas. Longe de se enquadrarem no contexto de uma economia de mercado em formação, as relações de troca estavam vinculadas intrinsecamente ao estabelecimento de alianças com os europeus". MONTEIRO, John. Negros da terra..., op. cit., 1995, p. 32.

${ }^{97}$ AVÉ-LALLEMANT, Robert. Viagem pelo norte..., op. cit., 1961, p. 103.

${ }^{98}$ DODT, Gustavo. Descrição dos rios..., op. cit., 1981, p. 91.
} 
ao passo que óleo de copaíba, borracha e outros produtos florestais estavam à livre disposição de quem fosse coletá-los. ${ }^{99}$

A partir desse ponto de vista, é possível pensar que os índios se sentiam de alguma forma beneficiados nas relações com os regatões, umas vezes mais, outras menos. A definição dos índios como ingênuos decorre da ênfase que tem sido dada ao valor de troca, ao valor de mercado dos objetos manufaturados. Importa, então, enfatizar o valor simbólico, o significado social dos objetos, eis que "é a cultura que atribui utilidade":100

É crucial que se note que o significado social de um objeto, o que o faz útil a uma certa categoria de pessoas, é menos visível por suas propriedades físicas que pelo valor que pode ter na troca. $\mathrm{O}$ valor de uso não é menos simbólico ou menos arbitrário que o valor-mercadoria. Porque a "utilidade" não é uma qualidade do objeto, mas uma significação das qualidades objetivas. ${ }^{101}$

Por essas razões, não se pode definir como "enganados" e "ingênuos" povos que têm outra percepção e expectativa daquilo que entendemos como comércio ou troca e que conferem aos objetos de nossa cultura outras significações e utilidades. Ao invés de se enfatizar os objetos apenas como bens de troca, importa percebê-los como agenciadores de relações sociais, como propiciadores de sociabilidade. Nesse sentido, o próprio consumo deve ser entendido como troca, uma troca de significados. ${ }^{102}$

Conforme afirmou Bruce Albert, "nenhuma sociedade, desde que consiga sobreviver, pode deixar de capturar e transfigurar em seus próprios termos culturais tudo que lhe é proposto ou imposto, até nas mais extremas condições de violência e sujeição". ${ }^{103}$ Os índios se apropriam dos objetos dos brancos, mas tais objetos passam por um processo de recontextualização em trocas ritualizadas, eles são reprocessados de modo a servirem como instrumentos de reprodução social e de reafirmação cultural. Os objetos são "processados" pela trama social, sua inserção nas culturas indígenas é mediada pelos valores desta, num esforço constante de imprimir nestes objetos sua marca

${ }^{99}$ HEMMING, John. Fronteira amazônica: a derrota dos índios brasileiros. São Paulo: Edusp, 2009, p. 323. ${ }^{100}$ SAHLINS, Marshal. Cultura e razão prática. Rio de Janeiro: Jorge Zahar Ed., 2003, p. 8.

${ }^{101}$ Idem, p. 169.

${ }^{102}$ BAUDRILLARD, Jean. Pour une critique de l'économie politique du signe. Paris: Gallimard, 1972.

${ }^{103}$ ALBERT, Bruce. Introdução: cosmologias do contato no norte-amazônico. In: ALBERT, Bruce $\mathcal{E}$ RAMOS, Alcida Rita. Pacificando o branco: cosmologias do contato no norte-amazônico. São Paulo: Editora Unesp; Imprensa Oficial do Estado, 2002, p. 15. 
distintiva. ${ }^{104}$ Somente assumindo esse ponto de vista conseguiremos recuperar a perspectiva indígena das trocas estabelecidas com os não indígenas, retirando estes povos da condição de vítimas ingênuas que lhes foi imposta.

\section{Referências bibliográficas}

ALBERT, Bruce. A fumaça do metal: história e representações do contato entre os Yanomami. Anuário Antropológico 89. Rio de Janeiro: Tempo Brasileiro, 1992, p. 151-189.

Introdução: cosmologias do contato no norte-amazônico. In: ALBERT, Bruce $\mathcal{E}$ RAMOS, Alcida Rita. Pacificando o branco: cosmologias do contato no norte-amazônico. São Paulo: Editora Unesp; Imprensa Oficial do Estado, 2002, p. 9-21.

AMANAJÁS, Hygino. D. Antonio de Macedo Costa, bispo do Pará e arcebispo da Bahia - sua vida e suas obras. Revista do Instituto Histórico e Geográfico do Pará, ano II, fasc. II. Belém, outubro de 1918, p. 207-218.

AVÉ-LALLEMANT, Robert. Viagem pelo norte do Brasil no anno de 1859. Rio de Janeiro: Ministério da Educação e Cultura, 1961 [1860].

BARRIGA, Letícia Pereira. Entre leis e baionetas: Independência e Cabanagem no médio Amazonas (1808-1840). Dissertação de mestrado, Programa de Pós-Graduação em História da Universidade Federal do Pará. Belém, 2014.

BATES, Henry Walter. O naturalista no rio Amazonas. Belo Horizonte: Itatiaia; São Paulo: Edusp, 1979 [1863].

BAUDRILLARD, Jean. Pour une critique de l'économie politique du signe. Paris: Gallimard, 1972.

BONILLA, Oiara. Cosmologia e organização social dos Paumari do médio Purus (Amazonas). Revista de Estudos e Pesquisas, v. 2. Funai. Brasília, nº 1, jul. 2005, p. 7-60.

BOTELHO, Ângela Vianna E REIS, Liana Maria. Dicionário histórico Brasil Colônia e Império. Belo Horizonte: Autêntica, 2002.

Brasil. Ministério da Agricultura. Relatório Apresentado á Assembléa Geral Legislativa na $3^{\mathrm{a}}$ sessão da $12^{\mathrm{a}}$ legislatura pelo Ministro e Secretário de Estado dos Negócios d'Agricultura, Commercio e Obras Públicas, Jesuíno Marcondes de Oliveira e Sá. Rio de Janeiro: Typographia Universal de Laemmert, 1865, anexo D.

CASTROVALVA, frei Pelino de. $O$ rio Tapajós, os capuchinhos e os índios Mundurucus (1871-1883). São Luís, Maranhão, 2000 [1884].

\footnotetext{
${ }^{104}$ HENRIQUE, Márcio Couto. Presente de branco: a perspectiva indígena dos brindes da civilização. In: XXVII REUNIÃO DA ANPUH. Comunicação apresentada no Simpósio temático "A presença indígena na história do Brasil". Natal, Rio Grande do Norte, 2013. Disponível em: http://www.snh2013.anpuh.org/resources/anais/27/1363044875_ARQUIVO_PresentedebrancoANPUH2013RTF.pdf, Acesso em: 30 abr. 2014.
} 
CUNHA, Manuela Carneiro da. Política indigenista nos século XIX. In: História dos índios no Brasil. São Paulo: Companhia das Letras, 1998 [1992], p. 133-154.

DODT, Gustavo. Descrição dos rios Parnaíba e Gurupi. Belo Horizonte: Ed. Itatiaia, 1981.

FERNANDES, João Azevedo. Selvagens bebedeiras: álcool, embriaguez e contatos culturais no Brasil colonial (séculos XVI-XVII). São Paulo: Alameda, 2011.

FERREIRA PENA, Domingos Soares. A região occidental da província do Pará. Pará: Typ. do Diário de Belém, 1869.

FLORIDO, Marcelo Pedro. O manakuni dos Deni: prestações e contraprestações no rio Cuniuá (AM). In: AMOROSO, Marta \& SANTOS, Gilton Mendes dos. Paisagens ameríndias: lugares, circuitos e modos de vida na Amazônia. São Paulo: Terceiro Nome, 2013, p. 275-298.

GOULART, José Alípio. O regatão: mascate fluvial da Amazônia. Rio de Janeiro: Editora Conquista, 1968.

Governo do Amazonas. Falla dirigida á Assembléa Legislativa da provincia do Amazonas, na abertura da $1^{\mathrm{a}}$ sessão ordinaria da $1^{\mathrm{a}}$ legislatura, pelo Exm. vice-prezidente da mesma provincia, o dr. Manoel Gomes Correa de Miranda, em 5 de setembro de 1852. Capital do Amazonas: Typ. de M. da S. Ramos, 1852.

Relatorio apresentado á Assembléa Legislativa Provincial, pelo Exc. Sr. doutor João Pedro Dias Vieira, dignissimo presidente desta provincia, no dia 8 de julho de 1856 por occasião da $1^{a}$ sessão ordinaria da $3^{\text {a }}$ legislatura da mesma Assembléa. Barra do Rio Negro: Typ. de F. J. S. Ramos, 1856.

Relatorio apresentado á Assembléa Legislativa da provincia do Amazonas na sessão ordinaria do $1^{\circ}$ de outubro de 1864, pelo dr. Adolfo de Barros Cavalcanti de Albuquerque Lacerda, presidente da mesma provincia. Pernambuco: Typ. de Manoel Figueiroa de Faria $\&$ Filho, 1864.

Relatorio com que o Illm. e Exm. Sr. dr. Adolpho de Barros Cavalcanti de A. Lacerda entregou a administração da provincia do Amazonas ao illm. e Exm. Sr. tenente coronel Innocencio Eustaquio F. de Araujo. Recife: Typ. do Jornal do Recife, 1865.

Relatorio apresentado á Assembléa Legislativa Provincial do Amazonas na $1^{\text {a }}$ sessão da $13^{\text {a }}$ legislatura em 25 de março de 1876 pelo Exm. Sr. presidente da provincia, dr. Antonio dos Passos Miranda. Pará: Typ. do Diario do Gram-Pará, 1876.

Governo do Pará. Fala dirigida pelo Exm. Sr. Conselheiro Jerônimo Francisco Coelho, presidente da província do Grão-Pará á Assembléa Legislativa provincial, na abertura da $2^{\mathrm{a}}$ sessão ordinária, da $6^{\mathrm{a}}$ legislatura, no dia $1^{\circ}$ de outubro de 1849. Pará: Typ. de Santos e Filhos, 1849.

Colecção das leis da provincia do Gram-Pará, tomo XVI, 1854. Pará: Typ. de Santos $\mathcal{E}$ Filhos, 1854, Lei ${ }^{\circ}$ 246, de 6 de setembro de 1854.

Relatório que o Exm. Sr. Dr. Antonio de Sá e Albuquerque, presidente da Província do Pará apresentou ao Exm. Sr. vice-presidente, Dr. Fábio Alexandrino de Carvalho Reis, ao passar-lhe a administração da mesma província em 12 de maio de 1860. Pará: Typ. comercial de Antonio José Rabelo Guimarães, 1860. 
Relatorio apresentado á Assembléa Legislativa da provincia do Pará na $1^{\text {a }}$ sessão da $13^{\text {a }}$ legislatura pelo Exm. Sr. presidente da provincia, dr. Francisco Carlos de Araujo Brusque em $1^{\circ}$ de setembro de 1862. Pará: Typ. de Frederico Carlos Rhossard, 1862.

Relatório apresentado a Assembléa Legislativa da província do Pará, na $2^{\mathrm{a}}$ sessão da $13^{\mathrm{a}}$ legislatura pelo Exm. Sr. Presidente da província Dr. Francisco Carlos de Araújo Brusque, em 1 de novembro de 1863. Pará: Typ. de Frederico Carlos Rhossard, 1863.

Relatorio dos negocios da provincia do Pará. At head of title: Dr. Couto de Magalhães, presidente do Pará, 1864. Pará: Typ. de Frederico Rhossard, 1864.

Relatório apresentado á Assembléa Legislativa provincial na $2^{\mathrm{a}}$ sessão da $17^{\text {a }}$ Legislatura, em 15 de agosto de 1871, pelo presidente da Província Dr. Abel Graça. Pará: Typ. do Diário do Grão-Pará, 1871.

Relatorio apresentado ao Exm. Sr. dr. Francisco Maria Corrêa de Sá e Benevides pelo exm. senr. dr. Pedro Vicente de Azevedo, por occasião de passar-lhe a administração da provincia, no dia 17 de janeiro de 1875. Pará: Typ. de F. C. Rhossard, 1875.

Relatorio apresentado pelo Exm. Sr. dr. Francisco Maria Corrêa de Sá e Benevides, presidente da provincia do Pará, á Assembléa Legislativa Provincial na sua sessão solemne de installação da $20^{\mathrm{a}}$ legislatura, no dia 15 de fevereiro de 1876. Pará: Travessa de São Matheus, 1876.

Relatório que ao Exm. Sr. Dr. João L. Paes de Sousa, primeiro vice-presidente da província do Pará apresentou o Exm. Sr. Dr. Carlos Augusto de Carvalho, ao passar-lhe a administração aos 16 de setembro de 1885. Pará: Typ. de Francisco da C. Júnior, 1885.

HARRIS, Mark. Rebellion on the Amazon: The Cabanagem, race, and popular culture in the North of Brazil, 1798-1840. Cambridge: Cambridge University Press, 2010.

HEMMING, John. Fronteira amazônica: a derrota dos índios brasileiros. São Paulo: Edusp, 2009.

HENRIQUE, Márcio Couto. Presente de branco: a perspectiva indígena dos brindes da civilização. XXVII REUNIÃO DA ANPUH. Comunicação apresentada no Simpósio temático "A presença indígena na história do Brasil", Natal, Rio Grande do Norte, 2013. Disponível em: http://www.snh2013.anpuh.org/resources/anais/27/1363044875_ARQUIVO_PresentedebrancoANPUH2013RTF. pdf. Acesso em: 30 abr. 2014.

O soldado-civilizador: Couto de Magalhães e os índios no Brasil do século XIX. In: ALVES, Claudia \& NEPOMUCENO, Maria de Araújo (org.). Militares e educação em Portugal e no Brasil, v. 1. $1^{\text {a }}$ ed. Rio de Janeiro: Faperj; Quartet, 2010, p. 45-83.

O general e os tapuios: linguagem, raça e mestiçagem em Couto de Magalhães (1864-1876). Dissertação de mestrado, Programa de Pós-Graduação em Ciências Sociais da Universidade Federal do Pará. Belém, 2003.

HOLANDA, Sérgio Buarque. Raízes do Brasil. 26a edição. São Paulo: Companhia das Letras, 1995. 
HOWARD, Catherine. A domesticação das mercadorias: estratégias Waiwai. In: ALBERT, Bruce (org.). Pacificando o branco: cosmologias do contato no norte-amazônico. São Paulo: Editora Unesp; Imprensa Oficial do Estado, 2002, p. 25-55.

LOPES, Simeia de Nazaré. O comércio interno no Pará oitocentista: atos, sujeitos sociais e controle entre 1840-1855. Dissertação de mestrado, NAEA. Belém, 2002.

McGRATH, David. Parceiros no crime: o regatão e a resistência cabocla na Amazônia tradicional. Novos Cadernos NAEA, vol. 2, n 2, dez. 1999, p. 57-72.

MEDEIROS, Vera B. Alarcón. Incompreensível colosso: a Amazônia no início do Segundo Reinado (1840-1850). Tese de doutorado, Universidade de Barcelona, Programa de Doutorado Estado e Sociedade na América e África, 2006.

MONTEIRO, John Manuel. Negros da terra: índios e bandeirantes nas origens de São Paulo. São Paulo: Companhia das Letras, 1995.

MONTEIRO, Mário Ypiranga. O regatão (notícia histórica). Manaus: Edições Planície, 1958.

MOOG, Vianna. O ciclo do ouro negro: impressões da Amazônia. Belém: Conselho Estadual de Cultura, 1975.

MORAIS, Raimundo. Na planície amazônica. Brasília: Senado Federal, Conselho Editorial, 2000 [1926].

MURPHY, Robert F.; MURPHY, Yolanda. As condições atuais dos Munduruku. Belém: Inst. de Antrop. e Etnologia do Pará, 1954.

[Nota avulsa]. Diário de Belém. Belém, 11 nov. 1869.

[Nota avulsa]. Treze de Maio. Belém, 4 jan. 1851.

NUNES, Francivaldo Alves. Sob o signo do moderno cultivo: Estado imperial e agricultura na Amazônia. Tese de doutorado, Programa de Pós-Graduação em História da Universidade Federal Fluminense. Rio de Janeiro, 2011.

O rio Tapajós. Diário de Belém. Belém, 22 de março de 1876.

OLIVEIRA FILHO, João Pacheco. O caboclo e o brabo: notas sobre duas modalidades de força de trabalho na expansão da fronteira amazônica no século XIX. In: Encontros com a Civilização Brasileira, v. 11, 1979, p. 101-147.

Pará. Discurso recitado pelo Exm. Sr. desembargador Manoel Paranhos da Silva Vellozo, presidente da provincia do Pará, na abertura da $1^{\mathrm{a}}$ sessão da $4^{\mathrm{a}}$ legislatura da Assembléa Provincial no dia 15 de agosto de 1844. Pará: Typ. de Santos \& menores, 1844.

PEREIRA, José Veríssimo da Costa. Regatões. In: IBGE. Tipos e aspectos do Brasil. Rio de Janeiro: IBGE, 1956, p. 34-38.

POMPA, Cristina. Para uma antropologia histórica das missões. In: MONTERO, Paula (org.). Deus na aldeia: missionários, índios e mediação cultural. São Paulo: Globo, 2006, p. 111-142.

REIS, Arthur Cezar Ferreira. O seringal e o seringueiro. Rio de Janeiro: Ministério da Agricultura, 1953.

RIBEIRO, Darcy. Os índios e a civilização: a integração das populações indígenas no Brasil moderno. Petrópolis: Vozes, 1979. 
RICCI, Magda. Cabanagem, cidadania e identidade revolucionária: o problema do patriotismo na Amazônia entre 1835 e 1840. Tempo, v. 11. Revista do Departamento de História da UFF. Rio de Janeiro, 2006, p. 15-40.

RODRIGUES, Joaquim Barbosa. Exploração e estudo do vale do Amazonas. Rio Tapajós. Rio de Janeiro: Typ. Nacional, 1875.

SAHLINS, Marshal. Cultura e razão prática. Rio de Janeiro: Jorge Zahar Ed., 2003.

SAMPAIO, Patrícia Melo. Política indigenista no Brasil imperial. In: GRINBERG, Keila \& SALLES, Ricardo. O Brasil imperial, vol. I: 1808-1831. Rio de Janeiro: Civilização Brasileira, 2009, p. 175-206.

SPOSITO, Fernanda. Nem cidadãos, nem brasileiros: indígenas na formação do Estado nacional brasileiro e conflitos na província de São Paulo (1822-1845). Tese de doutorado, FFLCH-USP. São Paulo, 2006.

TAVARES BASTOS, Aureliano Cândido. O valle do Amazonas. Rio de Janeiro: B. L. Garnier, 1866.

TOCANTINS, Antonio Manuel Gonçalves. Estudo sobre a tribu Mundurucu. Revista Trimensal do Instituto Histórico Geographico e Ethnographico Brasileiro, tomo XL. Rio de Janeiro: B. L. Garnier, 1877, p. 73-161.

VENÂNCIO, Renato Pinto $\mathcal{E}$ FURTADO, Júnia Ferreira. Comerciantes, tratantes e mascates. In: PRIORE, Mary Del (org.). Revisão do paraíso: os brasileiros e o Estado em 500 anos de história. Rio de Janeiro: Campus, 2000, p. 95-113.

VERÍSSIMO, José. Primeiras páginas (Viagem no sertão - quadros paraenses - estudos). Belém: Typographia Guttemberg, 1878. A pesca na Amazônia. Rio de Janeiro: Livraria Clássica de Alves \& C., 1895. Estudos amazônicos. Belém: UFPA, 1970.

WALLACE, Alfred Russel. Viagens pelos rios Amazonas e Negro. Belo Horizonte: Itatiaia; São Paulo: Edusp, 1979 [1853].

WEINSTEIN, Bárbara. A borracha na Amazônia: expansão e decadência (1850-1920). São Paulo: Hucitec/Edusp, 1993. 